\title{
GAMBARAN KARAKTERISTIK DAN ADHERENCE PASIEN DENGAN TERAPI SECOND-LINE MDR-TB DI RSUD ABDUL WAHAB SJAHRANIE SAMARINDA
}

\author{
Zul Zaahida Nur*, Nurul Annisa, Adam M. Ramadhan \\ ${ }^{1}$ Laboratorium Penelitian dan Pengembangan Kefarmasian "Farmaka Tropis", \\ Fakultas Farmasi, Universitas Mulawarman, Samarinda, Indonesia \\ ${ }^{2}$ Kelompok Bidang Ilmu Farmasi Klinik dan Komunitas, Fakultas Farmasi, \\ Universitas Mulawarman, Samarinda, Indonesia \\ *Email: zaazagetho@ymail.com
}

\begin{abstract}
The Directly Observed Treatment Shortcourse (DOTS) program with HRZE therapy (first line) is Tuberculosis treatment that is carried out for 6-8 months with low adherence (non adherence) which causes respondents to become MDR-TB. MDR-TB second-line therapy is a complex therapeutic regimen and the side effects that are felt are greater compared to first-line therapy. This study aims to describe the characteristics and adherence of patients with MDR-TB second-line therapy at Abdul Wahab Hospital Sjahranie Samarinda. This research was conducted descriptively by means of retrieving data retrospectively using purposive sampling technique. The results of this study were in the form of the characteristics of MDR-TB patients, who underwent intensive treatment as much as $12.1 \%$, who underwent advanced treatment as much as $87.9 \%$, who underwent satellite treatment as many as $69.7 \%$, who underwent treatment in the center as many as 30.3\%, 21.2\% of those with comorbidities, $78.8 \%$ of those who did not have co-morbidities, $63.6 \%$ of men, $36.4 \%$ of women, 90 of 18-55 years of age, 9\%, at the age of $>55$ years as much as $9.1 \%$, working as many as $63.6 \%$, and those who did not work as much as $36.4 \%$. As well as adherence to MDR-TB patients at Abdul Wahab Sjahranie Hospital in Samarinda, there were $72.7 \%$ of adherence respondents and $27.3 \%$ of non adherence patients.
\end{abstract}

Keywords: Adherence, characteristics, multi drug resistant tuberculosis (MDR-TB)

\begin{abstract}
ABSTRAK
Program Directly Observed Treatment Shortcourse (DOTS) dengan terapi HRZE (first line) adalah pengobatan Tuberkulosis yang dilakukan selama 6-8 bulan dengan kepatuhan yang rendah (non adherence) yang menyebabkan responden menjadi MDR-TB. Terapi second-line MDR-TB adalah regimen terapi yang rumit dan efek samping yang dirasakan lebih besar dibandingkan dengan terapi first-line. Penelitian ini bertujuan untuk mengetahui gambaran karakteristik dan adherence pasien dengan terapi second-line MDRTB di RSUD Abdul Wahab Sjahranie Samarinda. Penelitian ini dilakukan secara deskriptif dengan cara pengambilan data secara retrospektif dengan menggunakan teknik purposive sampling. Hasil penelitian ini berupa karakteristik pasien MDR-TB yaitu yang menjalani pengobatan tahap intensif sebanyak 12,1\%, yang menjalani pengobatan tahap lanjutan
\end{abstract}


sebanyak $87,9 \%$, yang menjalani pengobatan di satelit sebanyak $69,7 \%$, yang menjalani pengobatan di pusat sebanyak $30,3 \%$, yang memiliki penyakit penyerta sebanyak $21,2 \%$, yang tidak memiliki penyakit penyerta sebanyak 78,8\%, laki-laki sebanyak $63,6 \%$, perempuan sebanyak $36,4 \%$, pada usia $18-55$ tahun sebanyak $90,9 \%$, pada usia $>55$ tahun sebanyak $9,1 \%$, yang bekerja sebanyak $63,6 \%$, dan yang tidak bekerja sebanyak $36,4 \%$. Serta adherence pasien MDR-TB di RSUD Abdul Wahab Sjahranie Samarinda adalah responden yang adherence sebanyak $72,7 \%$ dan non adherence sebanyak $27,3 \%$.

Kata Kunci: Adherence, karakteristik, multi drug resistant tuberculosis (MDR-TB)

DOI: https://doi.org/10.25026/mpc.v8i1.335

\section{PENDAHULUAN}

Tuberkulosis paru merupakan infeksi yang disebabkan oleh Mycobacterium tuberculosis (bisa juga disebabkan oleh $M$. bovis dan africanum), yang pada umumnya menyerang paruparu dan sebagian menyerang di luar paru, seperti kelenjar getah bening, kulit, usus atau saluran pencernaan, selaput otak dan bagian tubuh lainnya. Organisme ini disebut pula sebagai Basil Tahan Asam (BTA). ${ }^{13}$

Penduduk usia dewasa lebih banyak yang meninggal disebabkan oleh infeksi bakteri Tuberkulosis dibanding penyebab penyakit infeksi lainnya. WHO memperkirakan bakteri ini membunuh sekitar 2 juta manusia setiap tahunnya. Tahun 2002-2020 diperkirakan sekitar 1 miliar manusia akan terinfeksi. Dengan kata lain pertambahan jumlah infeksi lebih dari 56 juta tiap tahunnya. ${ }^{13}$

Penyebab utama meningkatnya TB adalah masalah kemiskinan pada berbagai kelompok masyarakat, seperti negara-negara yang berkembang, kegagalan program TB, perubahan demografik karena meningkatnya penduduk dunia dan perubahan struktur umur dan kependudukan, dampak pandemik HIV.

Untuk menanggulangi dan mengendalikan masalah TB, WHO telah merekomendasikan strategi Directly Observed Treatment Shortcourse (DOTS) sejak tahun 1995. Fokus utama strategi DOTS adalah penemuan dan penyembuhan pasien. Dalam penanggulangannya, salah satu target penting yang harus dicapai adalah menyembuhkan $85 \%$ kasus TB paru menular yang dapat dideteksi, dan berhasil setidaknya 70\% kasus TB menular di masyarakat. Sedikitnya terdapat 3 (tiga) faktor yang menyebabkan tingginya kasus $\mathrm{TB}$ di Indonesia antara lain lamanya pengobatan TB (minimal 6 bulan) sehingga sering mengancam penderita untuk putus berobat, perkembangan penyakit Aqcuired Immune Deficiency Syndrome (AIDS) yang makin cepat, dan munculnya masalah Multi Drug Resistant Tuberculosis (MDR-TB). Adanya fenomena MDR-TB telah memperparah keadaan penyakit TB dan menghambat program penanggulangan $\mathrm{TB}$ di dunia termasuk Indonesia. ${ }^{4}$

MDR-TB adalah salah satu jenis resistensi basil TB terhadap setidaknya dua Obat Anti Tuberkulosis (OAT) lini pertama yaitu Isoniazid dan Rifampisin. MDR-TB menjadi tantangan baru dalam program pengendalian TB karena penegakan diagnosis yang sulit, tingginya angka kegagalan terapi dan kematian. Pengobatan bagi penderita MDR-TB lebih sulit, dengan angka keberhasilan hanya sekitar $50 \%$ dan biaya pengobatan yang mahal bahkan sampai 100 kali lebih 
mahal dibandingkan dengan pengobatan TB tanpa MDR, sehingga bagi negara berkembang menjadi beban yang sangat berat dalam penanggulangannya. ${ }^{6}$

Resistensi terhadap OAT sangat erat hubungannya dengan pengobatan yang memiliki kemungkinan 4 kali lebih tinggi untuk terjadi resistensi dan $10 \mathrm{kali}$ lipat terjadinya MDR-TB. Kasus MDRTB merupakan kasus yang sulit untuk ditangani karena efek samping yang lebih banyak, biaya yang lebih besar dan hasil yang kurang memuaskan. ${ }^{12}$

Pengobatan untuk penderita MDR-TB juga memerlukan waktu yang lama yaitu sekitar 18-24 bulan dengan obat suntik selama minimal 6 bulan. Obat yang digunakan untuk pengobatan MDRTB yaitu OAT lini kedua yang memiliki toksisitas melebihi obat lini pertama yang menyebabkan timbulnya efek samping pada penderita selama pengobatan. ${ }^{5}$

Penelitian ini bertujuan untuk mengetahui gambaran karakteristik dan adherence pasien dengan terapi secondline MDR-TB di RSUD Abdul Wahab Sjahranie Samarinda.

\section{METODE}

Penelitian ini dilakukan secara deskriptif dengan pengambilan data yang secara retrospektif. Pengambilan data dilakukan selama 3 bulan dengan teknik purposive sampling yang dianalisis secara deskriptif. Data penelitian diperoleh dari rekam medik responden MDR-TB.

Populasi penelitian adalah semua pasien penderita Multi Drug Resistant Tuberculosis (MDR-TB) di instansi rawat jalan RSUD Abdul Wahab Sjahranie Samarinda. Sampel penelitian adalah pasien yang termasuk dalam kriteria inklusi. Kriteria inklusi pengambilan sampel untuk penelitian ini adalah pasien MDR-TB yang menjalani pengobatan minimal 6 bulan dan berusia $>18$ tahun. Kriteria eksklusi adalah pasien meninggal pada saat pengobatan, pasien tidak memiliki data rekam medik yang lengkap, dan pasien menghilang atau berhenti pada saat pengobatan baik pada tahap intensif maupun lanjutan.

Pengumpulan data dilakukan dengan mencatat dahulu beberapa parameter yaitu nama, nomor rekam medik, usia, jenis kelamin, pekerjaan, tempat berobat, penyakit penyerta, tahap pengobatan, adherence dan hasil pemeriksaan BTA. Teknik analisis data pada penelitian ini dilakukan dengan menganalisis berdasarkan data rekam medik pasien dalam melakukan pengobatan MDR-TB.

\section{HASIL DAN PEMBAHASAN}

Hasil penelitian ini menunjukkan bahwa terdapat sebanyak 33 pasien MDR-TB yang telah dinyatakan positif MDR-TB di RSUD Abdul Wahab Sjahranie Samarinda. Penelitian ini menggunakan data rekam medik dengan 33 pasien dari total keseluruhan pasien MDR-TB tersebut yang ditetapkan berdasarkan purposive sampling yang memenuhi kriteria inklusi.

\section{Karakteristik Pasien MDR-TB}

Karakteristik pasien MDR-TB adalah berupa usia, jenis kelamin, pekerjaan, tempat berobat, penyakit penyerta, dan tahap pengobatan. Karakteristik ini digunakan untuk mengetahui gambaran karakteristik pasien MDR-TB di RSUD Abdul Wahab Sjahranie Samarinda.

Karakteristik berdasarkan tahap pengobatan terbanyak yaitu pada tahap lanjutan sebanyak 29 responden $(87,9 \%)$ dan pada tahap intensif sebanyak 4 responden $(12,1 \%)$ Sedangkan, adherence responden dengan tahap lanjutan memiliki angka yang lebih besar yaitu sebanyak 20 responden $(60,6 \%)$ dengan jumlah non adherence yaitu sebanyak 9 responden (27,2\%), dibandingkan adherence responden dengan tahap intensif yaitu sebanyak 4 responden $(12,1 \%)$ dengan jumlah non adherence sebanyak 0 responden (tidak 
ada). Pengaruh kepatuhan terhadap tahap pengobatan merupakan salah satu faktor penentu keteraturan responden dalam menjalani pengobatan MDR-TB. Menurut penelitian yang dilakukan oleh Erni, dkk (2010), lama pengobatan mempengaruhi kepatuhan responden dalam menjalani pengobatan, artinya semakin lama keluhan yang diderita penderita maka akan semakin tidak patuh untuk datang berobat. Hal ini disebabkan karena kondisi kesehatan penderita yang lemah, gizi yang kurang dan keparahan penyakit yang diderita. ${ }^{2}$

Tabel 1. Karakteristik Pasien MDR-TB

\begin{tabular}{lccc}
\hline \multirow{2}{*}{ Karakteristik } & \multicolumn{2}{c}{ Adherence } & Jumlah \\
\cline { 2 - 3 } & $\begin{array}{c}\text { Adherence } \\
\mathrm{n}(\%)\end{array}$ & $\begin{array}{c}\text { Non Adherence } \\
\mathrm{n}(\%)\end{array}$ & $\mathrm{n}(\%)$ \\
\hline $\begin{array}{l}\text { Tahap Pengobatan } \\
\text { Intensif }\end{array}$ & $4(12,1)$ & $0(0,0)$ & $4(12,1)$ \\
$\quad$ Lanjutan & $20(60,6)$ & $9(27,3)$ & $29(87,9)$ \\
\hline Tempat Berobat & $15(45,5)$ & $8(24,2)$ & $23(69,7)$ \\
$\quad$ Satelit & $9(27,3)$ & $1(3,0)$ & $10(30,3)$ \\
$\quad$ Pusat & $5(15,1)$ & $2(6,1)$ & $7(21,2)$ \\
\hline Penyakit Penyerta & $19(57,6)$ & $7(21,2)$ & $26(78,8)$ \\
$\quad$ Ada & $13(39,4)$ & $8(24,2)$ & $21(63,6)$ \\
$\quad$ Tidak Ada & $11(33,4)$ & $1(3,0)$ & $12(36,4)$ \\
\hline Jenis Kelamin & & & \\
Laki-laki & $23(69,7)$ & $7(21,2)$ & $30(90,9)$ \\
$\quad$ Perempuan & $1(3,0)$ & $2(6,1)$ & $3(9,1)$ \\
\hline Usia & $14(42,4)$ & $7(21,2)$ & $21(63,6)$ \\
$\quad \begin{array}{l}\text { 18-55 tahun } \\
>55 \text { tahun }\end{array}$ & $10(30,3)$ & $2(6,1)$ & $12(36,4)$ \\
\hline Pekerjaan & & &
\end{tabular}

Pengobatan satelit merupakan pengobatan yang dilakukan di Puskesmas terdekat dari tempat asal responden dengan rekomendasi dan pengawasan yang tetap dilakukan langsung dari rumah sakit pusat, pelaporan pengobatan dan kepatuhan responden dalam menjalani pengobatan dilakukan oleh Puskesmas yang bertanggung jawab kepada pihak Rumah Sakit Abdul Wahab Sjahranie Samarinda yang juga merupakan sebagai pusat pengobatan MDR-TB di Kalimantan.

Karakteristik berdasarkan tempat berobat terbanyak yaitu pada responden yang menjalani pengobatan di satelit sebanyak 23 responden $(69,7 \%)$ dan pada responden yang menjalani pengobatan di pusat sebanyak 10 responden $(30,3 \%)$. Sedangkan, adherence responden yang menjalani pengobatan di satelit memiliki angka yang lebih besar yaitu 15 responden $(45,5 \%)$ dengan jumlah non adherence yaitu 8 responden (24,2\%), dibandingkan responden yang menjalani pengobatan di pusat yang adherence yaitu 9 responden $(27,3 \%)$ dengan jumlah non adherence yaitu 1 responden $(3,0 \%)$.

Responden yang menderita MDRTB di RSUD Abdul Wahab Sjahranie Samarinda lebih banyak memilih menjalani pengobatan secara satelit. Jarak 
tempat berobat yang jauh dapat menjadi salah satu faktor yang dapat menyebabkan meningkatnya angka kejadian MDR-TB, dimana responden yang mengalami kegagalan pengobatan lini pertama baik akibat kelalaian dalam menjalani pengobatan maupun lemahnya imunitas tubuh susah untuk dideteksi karena kurangnya alat penunjang yang dapat mendeteksi bakteri Tuberkulosis yang resistan sehingga menyebabkan penanganan responden MDR-TB tidak dapat dilakukan dengan segera. Hal ini disebabkan banyak responden yang berasal dari luar daerah yang menjalani pengobatan MDR-TB, untuk mengurangi biaya dalam menjalani pengobatan responden dialihkan menjalani pengobatan di Puskesmas terdekat asal masing-masing responden.

Penyakit penyerta menjadi salah satu karakteristik responden dalam penelitian ini, penyakit penyerta yang diderita oleh responden dalam penelitian ini diantaranya adalah Diabetes Mellitus, Hipertensi dan penyakit paru-paru lainnya. Sebanyak 7 responden $(21,2 \%)$ memiliki penyakit penyerta dan 26 responden $(78,8 \%)$ tidak memiliki penyakit penyerta, dimana sebanyak 2 responden menderita Diabetes Mellitus, 2 responden menderita Diabetes Mellitus disertai Hipertensi, dan 3 responden menderita penyakit paru-paru lainnya. Sedangkan, adherence responden yang tidak memiliki penyakit penyerta dengan angka yang lebih besar yaitu 19 responden $(57,6 \%)$ dengan jumlah non adherence yaitu 7 responden (21,2\%), dibandingkan dengan adherence responden yang memiliki penyakit penyerta yaitu 5 responden $(15,1 \%)$ dengan jumlah non adherence yaitu 2 responden $(6,1 \%)$.

Penderita Diabetes Mellitus cenderung memiliki potensi terinfeksi penyakit Tuberkulosis bahkan rentan meningkat menjadi Multi Drug Resistant Tuberculosis (MDR-TB). Hal tersebut terjadi karena kondisi tekanan gula darah yang tinggi merupakan lingkungan yang cukup baik untuk perkembangan bakteri Mycobacterium tuberculosis, dimana gula merupakan salah satu nutrisi bagi bakteri untuk berkembang dan aktif. Selain itu, Diabetes Mellitus merupakan salah satu penyakit yang dapat menyebabkan menurunnya imunitas tubuh sehingga kemungkinan untuk terinfeksi bakteri Tuberkulosis yang resistan lebih mudah, hal ini berhubungan dengan kontrol gula darah yang buruk. Kontrol gula darah yang buruk dapt menyebabkan gangguan fungsi fagositosis, kemotaksis, reactive oxygen species (ROS) dan fungsi sel Th. ${ }^{3}$ Sedangkan, penyakit penyerta Hipertensi tidak mempengaruhi penyakit Tuberkulosis yang diderita oleh responden, kebanyakan responden yang menderita Hipertensi merupakan penyakit yang sudah diderita oleh responden sebelum menderita MDR-TB.

Adherence berdasarkan penyakit penyerta responden MDR-TB dipengaruhi oleh jenis penyakit dan jumlah obat yang diterima serta efek samping yang diterima oleh responden akibat pengobatan. Responden yang menderita Diabetes Mellitus umumnya diberikan injeksi insulin, Glibenklamid atau Metformin, sedangkan untuk Hipertensi pemberian obatnya tidak terdata direkam medik MDR-TB. Beberapa obat tersebut berinteraksi dengan pengobatan MDR-TB, seperti obat antidiabetes yang diberikan secara oral dapat menurunkan aktivitas OAT seperti Rifampisin sebesar 53\%. Dalam kasus MDR-TB obat antidiabetes tidak mempengaruhi kerja OAT, namun Diabetes Mellitus dapat menurunkan sistem imunitas tubuh dimana kadar gula yang tinggi akan memicu terjadinya efek imunologis yang berdampak pada penurunan fungsi neutrophil, monosit maupun limfosit. ${ }^{8}$

Karakteristik berdasarkan jenis kelamin pada pasien MDR-TB sebagian besar terjadi pada laki-laki yaitu sebanyak 21 responden $(63,6 \%)$ dan 
perempuan sebanyak $12(36,4 \%)$. Sedangkan, adherence responden pada jenis kelamin laki-laki memiliki angka yang lebih besar yaitu 13 responden $(39,4 \%)$ dengan jumlah non adherence yaitu 8 responden $(24,2 \%)$, dibandingkan adherence responden pada jenis kelamin perempuan yaitu sebanyak 11 responden $(33,4 \%)$ dengan jumlah non adherence sebanyak 1 responden $(3,0 \%)$.

Angka kejadian MDR-TB lebih tinggi pada laki-laki diduga akibat perbedaan pajanan dan resiko infeksi. ${ }^{15}$ Banyaknya jenis kelamin laki-laki yang menderita MDR-TB diketahui dapat dipengaruhi oleh aktifitas yang dilakukan sehingga menjadi penyebab responden tidak patuh dalam menjalani pengobatan MDR-TB.

Menurut hasil penelitian Rifaah (2014) bahwa jenis kelamin laki-laki cenderung lebih sulit untuk diatur sehingga kemungkinan untuk mangkir akan lebih besar dibandingkan jenis kelamin perempuan. Kecenderungan lakilaki lebih tinggi untuk mangkir berobat kemungkinan karena aktivitasnya lebih tinggi dalam sehari-harinya dan beberapa dengan alasan laki-laki merupakan salah satu tulang punggung keluarga yang harus bekerja. Selain itu, laki-laki juga sebagian besar mempunyai kebiasaan merokok, minum alkohol dan menggunakan obat-obatan terlarang sehingga dapat menyebabkan menurunnya sistem pertahanan tubuh. ${ }^{10}$

Karakteristik berdasarkan usia didapatkan bahwa kelompok usia yang terbanyak adalah pada rentang usia 18-55 tahun yaitu sebanyak 30 responden $(90,9 \%)$ dan pada rentang usia $>55$ tahun sebanyak 3 responden $(9,1 \%)$ dengan usia termuda 22 tahun dan tertua 61 tahun. Sedangkan, adherence responden dengan usia 18-55 tahun memiliki angka yang lebih besar yaitu sebanyak 23 responden $(69,7 \%)$ dengan jumlah non adherence sebanyak 7 responden (21,2\%), dibandingkan adherence responden dengan usia $>55$ tahun yaitu 1 responden
$(3,0 \%)$ dengan jumlah non adherence sebanyak 2 responden (6,1\%). Hasil tersebut serupa dengan pelaporan kasus MDR-TB secara global oleh WHO, dimana usia sekitar 25-54 tahun merupakan usia produktif secara ekonomi mengalami Tuberkulosis. Usia produktif secara ekonomi merupakan usia dimana seseorang berada pada tahap untuk bekerja atau menghasilkan sesuatu baik untuk diri sendiri maupun orang lain.

Menurut penelitian yang dilakukan oleh Munir, dkk (2010), MDRTB lebih banyak menyerang pada golongan usia produktif yaitu $35,6 \% .^{9}$ Hal ini selaras dengan penelitian Pomeranz, dkk (2007) bahwa 90\% orang yang terinfeksi oleh Mycobacterium tuberculosis di negara berkembang adalah usia di bawah 50 tahun. Kedua penelitian tersebut mendukung hasil penelitian ini, dimana didapatkan hasil yaitu usia di bawah 55 tahun. ${ }^{11}$

Karakteristik berdasarkan status pekerjaan, dimana responden yang bekerja sebanyak 21 responden $(63,6 \%)$ dan tidak bekerja sebanyak 12 responden (36,4\%). Sedangkan, adherence responden dengan status bekerja memiliki angka yang lebih besar yaitu sebanyak 14 responden $(42,4 \%)$ dengan jumlah non adherence sebanyak 7 responden (21,2\%), dibandingkan adherence responden dengan status tidak bekerja yaitu sebanyak 10 responden $(30,3 \%)$ dengan jumlah non adherence sebanyak 2 responden $(6,1 \%)$.

Pekerjaan merupakan salah satu faktor yang dapat mempengaruhi prevalensi angka kejadian MDR-TB, hal tersebut dipengaruhi oleh aktivitas yang banyak yang menyebabkan kelalaian dalam menjalani pengobatan MDR-TB. Selain itu, banyaknya aktivitas yang dilakukan diketahui dapat menurunkan imunitas tubuh pada beberapa responden. Sistem imun dalam tubuh akan menghambat bakteri Tuberkulosis yang masuk ke dalam tubuh melalui mekanisme alami dengan membentuk jaringan parut pada 
sel tubuh, sehingga apabila sistem imun tubuh melemah akan mengakibatkan bakteri Tuberkulosis bertambah banyak membentuk tuberkel di rongga paruparu. ${ }^{7}$ Hal tersebut mengakibatkan proses penyembuhan menjadi rumit, karena membutuhkan waktu yang lama.

\section{Adherence Pasien MDR-TB}

Adherence adalah kemauan individu untuk melaksanakan perintah yang disarankan oleh orang yang berwenang yaitu dokter, perawat dan petugas kesehatan lainnya. Pasien dikatakan adherence apabila tidak pernah absen untuk minum obat, sedangkan pasien dikatakan non adherence apabila ada satu kali tidak hadir untuk minum obat dengan melihat dari daftar minum obat.

Berdasarkan hasil penelitian yang dilakukan maka dapat diketahui bahwa responden yang adherence sebanyak $72,7 \%$ dan non adherence sebanyak $27,3 \%$.

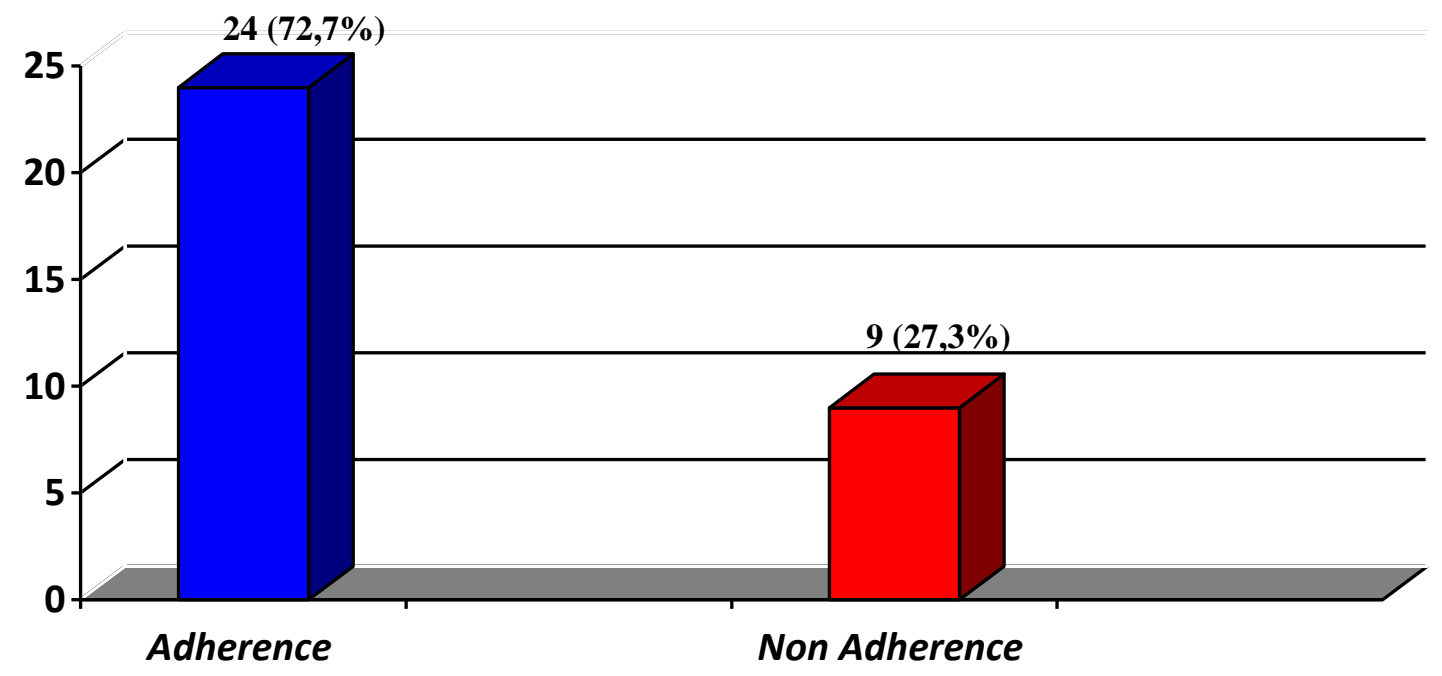

Gambar 1. Adherence Pasien MDR-TB

Dari hasil penelitian tersebut maka dapat diketahui jumlah responden adherence lebih banyak yaitu sekitar $72,7 \%$ responden patuh minum obat daripada jumlah responden non adherence. Hasil penelitian yang dilakukan Dhyantari (2013) tentang kepatuhan minum obat pada pasien Tuberkulosis didapatkan hasil bahwa 94,44\% responden patuh minum obat dalam fase intensif OAT. Penelitian oleh Bello dan Itiolla (2010) yang dilakukan di Iliorin, Nigeria juga mendapatkan hasil yang serupa, didapatkan tingkat kepatuhan minum obat yang tinggi yaitu sebesar $94,6 \%$ pada populasi yanng diteliti. Tingginya tingkat adherence pengobatan pada responden dapat disebabkan oleh beberapa faktor pendukung, yaitu 1) obat-obatan dan layanan kesehatan diberikan secara gratis, 2) regimen dosis satu kali sehari selama fase intensif, 3) efek samping yang ringan dapat dikoreksi, misalnya mual, 4) instruksi tertulis yang telah jelas tentang aturan minum obat, 5) pusat pelayanan kesehatan yang mudah diakses oleh masyarakat. Faktor lain yaitu responden 
yang sebagian besar berada di fase awal pengobatan mendukung untuk terjadinya adherence yang tinggi dikarenakan masih disiplinnya responden terhadap pengobatan yang dijalani. Faktor kekambuhan juga merupakan penyebab responden takut untuk tidak menjalani pengobatan dengan baik, karena dengan adannya kekambuhan berarti responden harus mengulang pengobatan dengan dosis dan jangka waktu yang lebih dari pengobatan.

Faktor yang dapat mempengaruhi adherence responden diantaranya adalah efek samping pengobatan MDR-TB, dukungan keluarga dan petugas kesehatan. Ketidakpatuhan tatalaksana pengobatan ini meliputi ketidakteraturan pengobatan, pemeriksaan dahak ulang pada akhir pengobatan fase awal dan satu bulan sebelum akhir pengobatan fase lanjutan. MDR-TB berkembang selama pengobatan Tuberkulosis ketika mendapatkan pengobatan yang tidak adekuat, dimana dapat juga disebabkan bila responden putus-putus berobat sebelum masa pengobatan selesai atau responden sering putus-putus minum obat selama menjalani pengobatan Tuberkulosis.

\section{KESIMPULAN}

Karakteristik pasien MDR-TB di RSUD Abdul Wahab Sjahranie Samarinda adalah yang menjalani pengobatan tahap intensif sebanyak $12,1 \%$, yang menjalani pengobatan tahap lanjutan sebanyak $87,9 \%$, yang menjalani pengobatan di satelit sebanyak 69,7\%, yang menjalani pengobatan di pusat sebanyak 30,3\%, yang memiliki penyakit penyerta sebanyak $21,2 \%$, yang tidak memiliki penyakit penyerta sebanyak $78,8 \%$, laki-laki sebanyak 63,6\%, perempuan sebanyak $36,4 \%$, pada usia 18-55 tahun sebanyak 90,9\%, pada usia $>55$ tahun sebanyak $9,1 \%$, yang bekerja sebanyak $63,6 \%$, dan yang tidak bekerja sebanyak $36,4 \%$. Serta adherence pasien MDR-TB di RSUD Abdul Wahab
Sjahranie Samarinda adalah responden yang adherence sebanyak $72,7 \%$ dan non adherence sebanyak $27,3 \%$.

\section{DAFTAR PUSTAKA}

[1] Bloss E, kuksa LL, Holtz TH, Riekstina V, Skripc'onoka V, Kammerer S., dkk. 2010. Journal Adverse Events Related To Multidrug-Resistant Tuberculosis Treatment, 14(3): 275-81, Latvia, 2000-2004. Int J Tuberc Lung Dis.

[2] Erni, Erawatyningsih, Purwanta, Heru Subekti. 2010. Faktor-Faktor Yang Mempengaruhi Ketidakpatuhan Berobat Pada Penderita Tuberkulosis Paru. Jurnal Berita Kedokteran Masyarakat Volume 25 Nomor 3.

[3] Fisher-Hoch SP, Whitnney E, McCormick JB, Crespo G, Smith B, Restrepo B., dkk. 2008. Journal Type 2 Diabetes and Multi Drug Resistant Tuberculosis 4(11-12): 888-93. Scan $\mathrm{J}$ Infected Dis.

[4] Kementerian Kesehatan Republik Indonesia. 2012. Pedoman Mannajerial Pelayanan Tuberkulosis dengan Strategi DOTS Di Rumah Sakit. Jakarta: Direktorat Bina Upaya Kesehatan.

[5] Kementerian Kesehatan Republik Indonesia. 2013. Pedoman Manajemen Terpadu Pengendalian Tuberkulosis Resisten Obat. Jakarta: Direktorat Jenderal Pengendalian Penyakit dan Penyehatan Lingkungan.

[6] Kementerian Kesehatan Republik Indonesia. 2014. Pedoman Nasional Pengendalian Tuberkulosis. Jakarta: Direktorat Jenderal Pengendalian Penyakit dan Penyehatan Lingkungan.

[7] Kumar, Abbas A.K., Fausto N., Aster JC, Robbins, Cotran. 2010. Pathologic Basis of Disease, Edisi 8. Saunders Elsevier. Philadelphia.

[8] Linda, DO. 2012. Hubungan Karakteristik Klien TB dengan 
Pengetahuan tentang MDR-TB. Skripsi. Jakarta: Fakultas Ilmu Keperawatan Universitas Indonesia.

[9] Munir, S., Nawas, A., Soetoyo, D. 2010. Pengamatan Pasien Tuberkulosis Paru dengan Multi Drug Resistant Tuberculosis (MDRTB) Di Poliklinik Paru RSUP Persahabatan. Jurnal Respiratory Indonesia Volume 30 Nomor 2. Jakarta.

[10]Rifaah, Munawwarah, Ida Leida, Wahiduddin. 2014. Gambaran Faktor Risiko Pengobatan Pasien MDR-TB RS Labuang Baji Kota Makassar Tahun 2013. Skripsi. Makassar: Bagian Epidemiologi Fakultas Kesehatan Masyarakat UNHAS.

[11] World Health Organization (WHO). 2002. WHO Global Tuberculosis Programme Fact Seet $N^{\circ} 104$. Geneva.
[12] World Health Organization (WHO). 2008. Guidelines For The Programmatic ManagementdrugResistant Tuberculosis Emergency Edition. The Organization Geneve. World Health Organization Media Centre.

[13] World Health Organization (WHO). 2011. Global Tuberculosis Control WHO Report. World Health Organization Media Centre.

[14] World Health Organization (WHO). 2012. Antimicrobial Resistance. World Health Organization Media Centre.

[15]Zainul, Muh. 2009. Hubungan Kebiasaan Merokok dengan Konversi Sputum Penderita TB Paru Di Klinik Jemedi Medan. Skripsi. Medan: Fakultas Kedokteran Universitas Sumatera Utara. 